Arq. Bras. Med. Vet. Zootec. s, v.73, n.5, p.1128-1136, 2021

\title{
Fish products developed from ground rainbow trout and tilapia fillet mixtures: Physico-chemical, microbiological and toxicological analyses
}

\author{
[Produtos de pescado elaborados a partir de misturas de carne moída de truta-arco-íris \\ (Oncorhynchus mykiss) e tilápia (Oreochromis sp.): análises físico-químicas, \\ microbiológicas e toxicológicas]

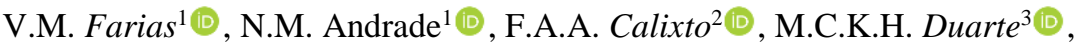 \\ L.A.M. Keller ${ }^{3 *}$ (D) E.F.M. Mesquita ${ }^{3}$ \\ ${ }^{1}$ Graduate, Universidade Federal Fluminense, Niterói, RJ, Brasil \\ ${ }^{2}$ Fundação Instituto de Pesca do Estado do Rio de Janeiro, FIPERJ, Rio de Janeiro, RJ, Brasil \\ ${ }^{3}$ Universidade Federal Fluminense, Niterói, RJ, Brasil
}

\begin{abstract}
Constant fishing industry innovations in response to consumer demands for novel, balanced healthy products exhibiting high nutritional value, as well as easy to prepare and ready to consume, have led to the emergence of new technologies. Among them, the development of products based on ground beef and fish mixtures are noteworthy. In this context, the purpose of this study was to develop products from different ground rainbow trout and tilapia fillet ratios, in the form of meatballs and nuggets, determining their proximate composition and physico-chemical, microbiological and toxicological characteristics. The average dry matter percentage of the developed products was $29.20 \pm 2.30 \%$, while mineral content was $1.45 \pm 0.55 \%$, lipid pulp content, $3.70 \pm 0.30 \%$ and crude pulp protein, $16.60 \pm 2.04 \%$. Total psychotropic counts remained below $10^{2} \mathrm{CFU} / \mathrm{g}$, for standard counting on aerobic microorganism plates. Histamine and sulfur-based compounds were not detected in any of the prepared samples. The purpose of the work proposal was to develop foods and technologies that can serve as standards, allowing for simple handling products that apply ground meat mixtures from different fish species to maintain adequate nutritional indices after processing.
\end{abstract}

Keywords: truticulture, fish technology, new products, innocuity

\section{RESUMO}

A constante inovação da indústria pesqueira, em resposta às demandas dos consumidores por novos produtos saudáveis, com alto valor nutritivo, balanceados, de fácil preparo e prontos para consumo, levou ao surgimento de novas tecnologias, entre elas o desenvolvimento de produtos à base de mistura de carne moída de pescado. Nesse contexto, a proposta deste trabalho é desenvolver produtos a partir de carne moída de pescado de truta-arco-íris e tilápia, confeccionando almôndegas e nuggets em diferentes proporções, com determinação da composição centesimal e de suas características físico-químicas,

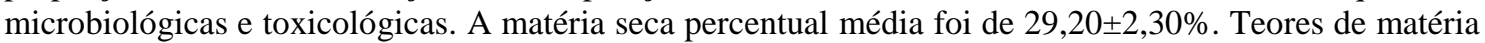
mineral nos produtos estão em $1,45 \pm 0,55 \%$. Os teores de lipídeos aferidos na polpa foram de $3,70 \pm 0,30 \%$, e os níveis de proteína bruta apresentados na polpa de $16,60 \pm 2,04 \%$. A contagem de psicrotróficos totais manteve-se abaixo de $10^{2} \mathrm{CFU} / \mathrm{g}$, para contagem padrão em placas de microorganismos aeróbicos. Nas amostras, não foram detectados níveis de histamina e de compostos à base de enxofre. A proposta de trabalho objetivou, por fim, desenvolver alimentos e tecnologias que possam servir como padrões, permitindo que produtos de manipulação simples e que utilizem misturas de carne moída de diferentes espécies de pescado mantenham índices nutricionais adequados após o processamento.

Palavras-chave: truticultura, tecnologia do pescado, novos produtos, inocuidade

*Corresponding author: luiz_keller@id.uff.br

Submitted: April 27, 2020. Accepted: May 24, 2021. 


\section{INTRODUCTION}

The continuous search for healthier food items by people, associated with practicality concerning their preparation, has become a current demand, mainly due to the various daily activities that are developed by modern society, mainly in large cities (Berizi et al., 2016). In this context, fish are considered both an excellent source of protein and a major income-generating business, mainly in developing countries, through extractive fishing reductions and greater aquaculture investments, which has become a promising and increasing activity (Lopes et al., 2016).

Salmonids are the main group of animals used in cold water fish farming. Among species belonging to the Salmonidae family, the rainbow trout is of paramount importance, as it can be reared worldwide and its industrial aquaculture growth is currently on the rise. Many investments have been made concerning studies to further develop relevant rainbow trout production issues, such as increased stocking density and productive and commercial productivity (Oncorhynchus..., 2017). Tilapia (Oreochromis sp.) introduction in Brazil took place in the $20^{\text {th }}$ century, and this species is currently the most produced in the country, due to its genetic and reproductive characteristics (Hilsdorf, 2018).

Fishing industry maintenance in the current consumer market is directly related to the ability to respond to the new consumer demands, through the development of new products that meet the requirements for healthy, balanced and easy to prepare food items, exhibiting high nutritional value, differentiated and less impactful to the modern routine (Ribeiro et al., 2018; Guimaraes et al., 2018). In this context, the development of new fish-based products is, thus, favored, not only by creating high nutritional value food items but also by taking advantage of a large amount of material that would otherwise be discarded. Technologies have emerged to target and favor the use of fish products as food sources, transforming them into nutritious products with good market acceptance, such as surimi, pates, dumplings, and "fish burgers" (Berizi et al., 2016; Ribeiro et al., 2018; Guimaraes et al., 2018).
Fish processing makes it possible to increase marketing options to different product shapes and sizes through the separation of edible parts, which have been widely applied in trout and tilapia processing, for example (Bykowski, 1994). The concept of Food Security, set by the Food and Agriculture Organization (FAO), is defined as "when everyone, at all times, has physical and economic access to sufficient, innocuous and nutritious food to satisfy their dietary needs and preferences regarding food in order to lead a healthy and active life" (The state..., 2014). When consumed frequently, fish aid in preventing cardiovascular diseases and controlling blood pressure, and also play important roles in lactation and neurological development (Avdalov, 2014).

In this context, this study aimed at the development of two fast-prepared products (meatballs and nuggets) based on a mixture of ground rainbow trout (Oncorhynchus mykiss) and tilapia (Oreochromis sp.) filets. These products were prepared at different ratios and characterized by determining their centesimal composition and other physicochemical, microbiological and toxicological parameters, to certify their final quality.

\section{MATERIAL AND METHODS}

Fresh trout and tilapia specimens were purchased from fish farms located in the city of Nova Friburgo, in the state of Rio de Janeiro, Brazil, between August and September 2019. Species were identified through specialized literature and by comparisons (Oncorhynchus..., 2018). The specimens were placed in an isothermal container with abundant ice and taken to the Fish and Aquatic Health Laboratory belonging to the Federal Fluminense University. At the laboratory, they were washed and biometric parameters were determined (weight and total length). The specimens were then skinned, eviscerated, beheaded and filleted. Each fillet was then ground in a manual meat grinder. Samples (250g) from the processed (base of the preparations) and cooked (meatballs and nuggets) samples were separated and vacuum packed for the physico-chemical, microbiological and toxicological analyses. All samples were analyzed in triplicate. 
The mixture between the two ground fish meats were tested at the following ratios: $100 \%$ tilapia and $100 \%$ trout (Control - C1 and C2, respectively), $90 \%$ trout and $10 \%$ tilapia (Treatment 1 - T1), 80\% trout and 20\% tilapia (Treatment 2 - T2), 70\% trout and 30\% tilapia (Treatment 3 - T3) and $60 \%$ trout and $40 \%$ tilapia (Treatment 4 - T4). After establishing the proposed mixtures ( $\mathrm{C} 1, \mathrm{C} 2, \mathrm{~T} 1, \mathrm{~T} 2, \mathrm{~T} 3$, and $\mathrm{T} 4)$, the products were adjusted to two general product formulations (Tables 1 and 2). Due to product characteristics, the nuggets were breaded after mixing using wheat flour and maintained chilled until preparation.

About $250 \mathrm{~g}$ of processed fish meat yielded ten meatballs and nuggets for each preparation (25gram portions).

The prepared products were placed in an insulated container and transported to the State Center for Research and Food Quality (CEPQA) belonging to the Agricultural Research Corporation of the State of Rio de Janeiro (PESAGRO-RIO) for physico-chemical and toxicological analyses. The microbiological analyses were performed at the Laboratory of Microbiological Control of Products of Animal Origin (LCMPOA), at the Federal Fluminense University.

Table 1. General meatball formula containing different ground trout (Oncorhynchus mykiss) and tilapia (Oreochromis sp.) meat ratios

\begin{tabular}{lcc}
\hline Ingredients & $\begin{array}{c}\text { Percentual } \\
\text { Ingredients (\%) }\end{array}$ & $\begin{array}{c}\text { Adding } \\
\text { in grams }\end{array}$ \\
\hline Sodium chloride & 0.7 & 1.62 \\
Onions & 7.0 & 16.20 \\
Garlic & 3.0 & 6.94 \\
Basil & 0.1 & 0.23 \\
Oregano & 0.1 & 0.23 \\
White pepper & 0.1 & 0.23 \\
(powder) & 0.5 & 1.00 \\
Turmeric & 88.5 & 234.54 \\
Ground fish fillet & & \\
\hline
\end{tabular}

Table 2. General nugget formula containing different ground trout (Oncorhynchus mykiss) and tilapia (Oreochromis sp.) meat ratios

\begin{tabular}{lcc}
\multicolumn{1}{c}{ Ingredients } & $\begin{array}{c}\text { Percentual } \\
\text { Ingredients }(\%)\end{array}$ & $\begin{array}{c}\text { Adding in } \\
\text { grams }\end{array}$ \\
\hline $\begin{array}{l}\text { Sodium } \\
\text { chloride }\end{array}$ & 0.6 & 1.62 \\
Onions & 6.2 & 16.20 \\
Garlic & 2.7 & 6.94 \\
Chives & 0.1 & 0.23 \\
Parsley & 0.1 & 0.23 \\
Black pepper & 0.1 & 0.23 \\
(powder) & 0.1 & 0.26 \\
Wheat flour & 0.1 & 1.00 \\
Lemon juice & 89.9 & 236.24 \\
Ground fish & & \\
filet & &
\end{tabular}

For the physico-chemical analyses, sample were pre-dried at $105^{\circ} \mathrm{C}$ and the following tests were carried out in triplicate, following Brazilian legislation established by the Ministry of Agriculture, Livestock and Supply (MAPA) (Brazil, 2018), based on the AOAC manual (Official..., 2005): dry matter; ash; crude protein (Micro Kjeldahl), hydrogen potential (pH); aqueous activity (Aw) (infrared assessments, Aqualab®); ether extract (Soxhlet method); BVT (total volatile bases); sodium contained in the obtained mineral matter (UV spectrophotometry at 593nm, Shimadzu® - Ks, USA).

The microbiological analyses were performed as described in the Compendium of Methods for the Microbiological Examination of Foods (Compendium..., 2015), following Brazil (2001). Coliforms were enumerated at $45^{\circ} \mathrm{C} / \mathrm{g}$, coagulase-positive Staphylococcil g, Salmonella spp. $/ 25 \mathrm{~g}$ were evaluated in the prepared products and Salmonella sp./25g, and coagulase-positive staphylococci/g counts were investigated in fresh fish. Additionally, for comparative purposes, the concentrations of mesophilic and psychotropic organisms were evaluated to highlight the sanitary quality of the developed products.

Toxicological analyses comprised the evaluation of the presence of hydrogen sulfide gas $\left(\mathrm{H}_{2} \mathrm{~S}\right)$ and histamine, according to Brazil (2018). 
Data were evaluated using parametric parameters (mean, standard deviation, maximum and minimum values) and tables. The statistical treatment was performed by comparing means and frequencies, considering statistical comparisons by the Tukey test and frequency assessments (ANOVA), at a significance level of $5 \%(p \leq 0.05)$ for comparison between treatments and experimental groups (Agresti, 2002).

\section{RESULTS AND DISCUSSION}

The fish specimens ranged between 32 and $45 \mathrm{~cm}$ total length, with an average of $35.22 \pm 5.0 \mathrm{~cm}$ and between $350.6 \mathrm{~g}$ (trout) and $1187.6 \mathrm{~g}$ (tilapia) total weight. Fillet yields of the gutted fish ranged between 28.08 and $48.87 \%$, averaging $38.02 \pm 6.99 \%$. Regarding total weight, yields varied between 27.04 and $47.06 \%$, averaging $36.23 \pm 6.65 \%$. The biometric parameters of both the tilapia and trout fillets were in accordance with FIPERJ (Relatório..., 2014), which describes specimens with total lengths between 19.0 and $60.0 \mathrm{~cm}$ and weight between 0.711 and $2.186 \mathrm{~kg}$.

The fillet yields of gutted trout fillets varied between $39.08 \%$ and $48.87 \%$, averaging $42.02 \% \pm 5.99 \%$, while tilapia fillets ranged between 37.04 and $57.06 \%$, averaging $46.23 \% \pm 6.65 \%$. The yields obtained in this study exhibited high commercial potential when compared to Signor et al. (2010), who described values of $48.50 \%$ for pacu fillets (Piaractus mesopotamicus), and $28.00 \%$ for Nile tilapia (Oreochromis niloticus), as reported by da Silva et al. (2016) in later studies.

The average proximate composition values of the prepared products and their controls are displayed in Table 3.

Table 3. Centesimal composition of ground tilapia (Oreochromis sp.) and trout (Oncorhynchus mykiss) pulp, fish meatballs, and fish nuggets.

\begin{tabular}{lcccc}
\hline Samples (*) & $\begin{array}{c}\text { Dry matter } \\
(\%)\end{array}$ & Crude Protein $(\%)$ & Lipids (\%) & Mineral (\%) \\
\hline Tilapia pulp (C1) & $27.20 \pm 1.30$ & $15.60 \pm 1.04$ & $4.80 \pm 0.30$ & $1.35 \pm 0.04$ \\
Trout pulp (C2) & $27.90 \pm 1.10$ & $17.80 \pm 2.16$ & $4.20 \pm 0.80$ & $1.55 \pm 0.05$ \\
Tilapia pulp meatballs (C1) & $30.10 \pm 1.10$ & $14.90 \pm 2.12$ & $4.20 \pm 0.60$ & $1.47 \pm 0.05$ \\
Trout pulp meatballs (C2) & $30.40 \pm 1.20$ & $15.00 \pm 2.00$ & $4.50 \pm 0.60$ & $1.87 \pm 0.05$ \\
Mixed pulp meatballs (T1) & $31.20 \pm 1.00$ & $14.50 \pm 1.00$ & $4.40 \pm 0.60$ & $1.92 \pm 0.05$ \\
Mixed pulp meatballs (T2) & $29.50 \pm 1.00$ & $15.00 \pm 1.00$ & $4.40 \pm 0.60$ & $1.92 \pm 0.05$ \\
Mixed pulp meatballs (T3) & $31.10 \pm 1.00$ & $14.30 \pm 1.00$ & $4.40 \pm 0.60$ & $1.92 \pm 0.05$ \\
Mixed pulp meatballs (T4) & $29.10 \pm 1.00$ & $15.10 \pm 2.10$ & $4.40 \pm 0.60$ & $1.92 \pm 0.05$ \\
Tilapia pulp nuggets (C1) & $29.10 \pm 1.10$ & $14.90 \pm 2.00$ & $4.20 \pm 0.60$ & $1.47 \pm 0.05$ \\
Trout pulp nuggets (C2) & $30.40 \pm 1.20$ & $13.90 \pm 2.00$ & $4.50 \pm 0.60$ & $1.87 \pm 0.05$ \\
Mixed pulp nuggets (T1) & $30.20 \pm 1.00$ & $13.10 \pm 2.10$ & $4.40 \pm 0.60$ & $1.92 \pm 0.05$ \\
Mixed pulp nuggets (T2) & $29.20 \pm 1.00$ & $13.10 \pm 2.10$ & $4.40 \pm 0.60$ & $1.92 \pm 0.05$ \\
Mixed pulp nuggets (T3) & $29.10 \pm 1.00$ & $13.10 \pm 2.10$ & $4.40 \pm 0.60$ & $1.92 \pm 0.05$ \\
Mixed pulp nuggets (T4) & $29.20 \pm 1.00$ & $13.10 \pm 2.10$ & $4.40 \pm 0.60$ & $1.92 \pm 0.05$ \\
\hline
\end{tabular}

$(*)$ Average $(\mathrm{n}=3)$ of triplicate analyses. Control $(\mathrm{C} 1$ and $\mathrm{C} 2)$; Treatment $1(\mathrm{~T} 1) 90 \%$ trout and $10 \%$ tilapia; Treatment 2 (T2) 80\% trout and 20\% tilapia; Treatment 3 (T3) 70\% trout and 30\% tilapia; Treatment 4 (T4) 60\% trout and $40 \%$ tilapia.

The importance of homogenizing the fish base mass (fish pulp) for product preparation is highlighted, due to the lack of any type of change in the final product appearance. The ground fish meat was mixed to obtain $\mathrm{C} 1, \mathrm{C} 2, \mathrm{~T} 1, \mathrm{~T} 2, \mathrm{~T} 3$, and $\mathrm{T} 4$. The products did not have any strong characteristic odor, presenting a homogeneous aspect, without the presence of any solid residue resulting in handler or consumer risks.
No statistical differences between physicalchemical parameters between $\mathrm{T} 1, \mathrm{~T} 2, \mathrm{~T} 3$, and T4 were observed $(p>0.05)$, considering that the proposed mixtures did not significantly influence nutritional indices when comparing treatments and the individual fresh ground trout and tilapia meat indices. This indicates that the processed meat mixtures may be a viable technological process. 
The average $\mathrm{pH}$ values of the ground fish meat samples and the finished products remained close to $6.20 \pm 0.30$, determined in the chilled samples and at the end of their processing. Aw values in the ground trout and tilapia meat and finished products averaged $0.90 \pm 0.15$, with a mean BVT value of $21.44 \pm 9.76 \mathrm{mg} \mathrm{N} / 100 \mathrm{~g}$.

All determined BVT values remained close to the average value, although some outliers were responsible for increased standard deviation. As fish is a highly perishable raw material, heterogeneity in single fish batches is noted. The observed deviation may also be associated with differences between specimens and the time between fish acquisition and processing. Some authors believe that a BVT analysis is one of the main methods to assess fish freshness. To Fontes et al. (2011), this method was crucial in assessing the quality of fish marketed in Portugal, widely applied worldwide for fish quality control. Similarly, values within established standards were reported by Guimaraes et al. (2018), of $\mathrm{pH} 6.15 \pm 0.40$ and BVT of $21.44 \pm 9.76 \mathrm{mg} \mathrm{N} / 100 \mathrm{~g}$.

BVT levels and $\mathrm{pH}$ indicate processing and food matrix quality. According to the Brazilian legislation, the maximum permitted BVT limit allowed for this type of product is $30 \mathrm{mg}$ of $\mathrm{N} / 100 \mathrm{~g}$ and $\mathrm{pH}$, between 6.5 to 6.8 (Brasil, 2018). Thus, despite the outliers detected herein, the developed products exhibited satisfactory quality levels.

The dry matter content detected in the ground meat and proposed formulations was $29.20 \% \pm 2.30 \%$. Similar studies with washed fish mechanically separated meat (MSM) report an average moisture content of $80.98 \%$. Moisture values in washed MSM can differ significantly, depending on the types of fish used to form the material (Sary et al., 2009).

Regarding the proposed meatballs and nuggets, dry matter content values were of $28.90 \% \pm 1.10 \%$ and $29.10 \% \pm 2.10 \%$, respectively. Therefore, a significant variability in moisture content and, consequently, dry matter was noted. As these products are a very hygroscopic material, handling care is necessary to maintain their quality, since nutritional product quality varies greatly with technological processing and species (Berizi et al., 2016).
The mineral matter content of the fish pulp was of $1.45 \% \pm 0.55 \%$. Sodium and potassium evaluations based on the mineral contents obtained herein considered percentage values of $0.05 \% \pm 0.03 \%$ and $0.06 \% \pm 0.03 \%$, respectively. Despite the addition of other raw materials during processing, no significant increase in sodium and potassium values were observed. The sodium content present in the final product is directly associated to several cardiovascular problems, being regulated by several agencies. The content determined in this study is in accordance to that proposed by the World Health Organization (WHO), which recommends a daily maximum sodium consumption of $5 \mathrm{~g}$ per day (Précoma and Oliveira, 2019).

However, according to the Brazilian Society of Cardiology (SBC), Brazil displays a sodium consumption of $2 \mathrm{~g}$ per capita per day, which is equivalent to approximately $5.0 \mathrm{~g}$ of salt per day (Précoma and Oliveira, 2019). If WHO standards were followed, a $15 \%$ reduction in deaths due to strokes and a $10 \%$ reduction of infarction episodes would occur in the country. In addition, according to the SBC, if sodium consumption were decreased, 1.5 million hypertensive individuals would no longer have to use antihypertensive drugs and their life expectancy would be increased by over four years (Tratamento..., 2021).

Because dietary preferences for salty foods and overall dietary habits are formed in childhood, it is logical to intervene concerning sodium consumption reduction and stimulation of fish consumption at this age, to avoid consuming a poorer quality diet overall, which puts children at risk for obesity and adult hypertension. Reducing the population-level consumption of processed foods high in sodium may be particularly impactful. Pediatric health care providers must understand the concerns regarding high dietary sodium, counsel families to reduce intake levels and support government and public health strategies to reduce high amounts of dietary sodium.

It is vital to encourage more varied diets, including quality proteins and, especially, adequate nutritionally, with the focus of this study developing processes that can encourage the adequate consumption of fish-based products. 
It is important to consider these data, since products able to unify easy technological processing, satisfactory nutritional value and practical consumption may be considered to assist in preventing both the consumption of products containing excess sodium chloride, such as sausages, and fish products, due to their nutritional characteristics, associated with foods indicated for the prevention of heart and vascular diseases.

The amount of lipids in the fish pulps and products were $3.70 \% \pm 0.30 \%$, in the meatballs, $3.20 \% \pm 0.80 \%$ and in the nuggets, $3.90 \% \pm 0.60 \%$. Gryschek et al. (2003) reported lipid contents of $4.23 \%$ and $1.70 \%$ in unwashed and washed Nile tilapia MSM, respectively, demonstrating that processing can interfere in material characterization, mainly concerning homogenization. In subsequent studies, Rebouças et al. (2012) reported lipids levels in the order of $4.46 \%$, and indicated that the difference in the author's observed levels and literature data is associated to several intrinsic and extrinsic fish specimen factors. Visentainer et al. (2007) reported comparative lipid indices for Brazilian marine fish and continental fish farming, indicating mostly values below $10 \%$. This evidences that the food items and seasonal conditions of the fishing process can influence fish nutritional parameters. Chemical lipid reactions are mainly favored by heat treatments, displaying technological importance in innumerable fish production stages, including raw material selection, product development, storage, processing and distribution, and are relevant in product technological development (German, 2012).

In the present study, crude protein was of $16.6 \pm 2.04 \%$ in fish pulp, and did not vary significantly between the ground meat immediately after preparation and the processed products. Moura et al. (2014) reported $15.61 \%$ of crude protein in breaded yellow hake fried for three minutes and 30 seconds at approximately $195^{\circ} \mathrm{C}$, similar to the values observed herein, mainly in the formulated nuggets. Contreras-
Guzmán (1994) when assessing tilapia pulp, consider NNP values around 344mg NNP/100g in Nile tilapia muscle as acceptable postprocessing values.

Ribeiro et al. (2018) considered that fish processing can influenced final product quality, demonstrating that good processing practices result in adequate final product quality through protein index maintenance and other data. Berizi et al. (2016) state that the application of mixtures or bioactive products in rainbow trout pulp or fillets do not significantly influence nutritional parameters of processed fish.

In the present study, fecal coliforms and Staphylococcus aureus counts were below the limit of detection $\left(<10^{1} \mathrm{CFU} / \mathrm{g}\right)$. Furthermore, the absence of Salmonella spp. in the raw material, from the handling to the storage period, were all within Brazilian legislation standards as can be seen in Table 4 (Brasil, 2001).

Regarding safety parameters, despite the risk of post-processing contamination, all products were considered safe according to recommended microbiological and toxicological standards (Brasil, 2001, 2018). The choice of applying a quality standard for products aimed at human consumption to the raw materials is due to the need to ensure final product safety, since raw material selection is an important factor in highly manipulated products.

Although not established in current legislations, the psychotropic bacteria count observed herein corroborate the hygienic quality of the developed products, indicating the possibility of chilled storage for a long period of time. However, comparative studies report that processing leads to microbiota food variations. For example, Gümüş et al. (2008), reported total aerobic mesophilic bacteria counts ranging from $3.16 \pm 0.04$ to $2.84 \pm 0.05 \mathrm{log} \mathrm{CFU} / \mathrm{g}$ and total coliform counts ranging from $2.73 \pm 0.01$ to $2.43 \pm 0.02 \log \mathrm{CFU} / \mathrm{g}$ both before and after product processing. 
Table 4. Microbiological counts (log CFU/g) of fecal coliforms, S. aureus and Salmonella spp.in fish pulp and the processed meatballs and nuggets developed herein

\begin{tabular}{lcccccc}
\hline & Fecal coliforms & \multicolumn{2}{c}{ S. aureus } & \multicolumn{2}{c}{ Salmonella spp } \\
\hline Samples (*) & Initial & $\begin{array}{c}\text { Storage after } \\
\text { 30 days }\end{array}$ & Initial & $\begin{array}{c}\text { Storage after } \\
\text { 30 days }\end{array}$ & Initial & $\begin{array}{c}\text { Storage after } \\
\text { 30 days }\end{array}$ \\
\hline Tilapia pulp (C1) & 1.0 & 1.0 & 1.0 & 1.0 & Absence & Absence \\
Trout pulp (C2) & 1.0 & 1.0 & 1.0 & 1.0 & Absence & Absence \\
Tilapia pulp meatball (C1) & 1.0 & 1.0 & 1.0 & 1.0 & Absence & Absence \\
Trout pulp meatball (C2) & 1.0 & 1.0 & 1.0 & 1.0 & Absence & Absence \\
Mixed pulp meatball (T1) & 1.0 & 1.0 & 1.0 & 1.0 & Absence & Absence \\
Mixed pulp meatball (T2) & 1.0 & 1.0 & 1.0 & 1.0 & Absence & Absence \\
Mixed pulp meatball (T3) & 1.0 & 1.0 & 1.0 & 1.0 & Absence & Absence \\
Mixed pulp meatball (T4) & 1.0 & 1.0 & 1.0 & 1.0 & Absence & Absence \\
Tilapia pulp nugget (C1) & 1.0 & 1.0 & 1.0 & 1.0 & Absence & Absence \\
Trout pulp nugget (C2) & 1.0 & 1.0 & 1.0 & 1.0 & Absence & Absence \\
Mixed pulp nugget (T1) & 1.0 & 1.0 & 1.0 & 1.0 & Absence & Absence \\
Mixed pulp nugget (T2) & 1.0 & 1.0 & 1.0 & 1.0 & Absence & Absence \\
Mixed pulp nugget (T3) & 1.0 & 1.0 & 1.0 & 1.0 & Absence & Absence \\
Mixed pulp nugget (T4) & 1.0 & 1.0 & 1.0 & 1.0 & Absence & Absence \\
\hline
\end{tabular}

(*) Average for the samples $(\mathrm{n}=3)$ analyzed in triplicate; LOD: $\log 1.0 \mathrm{CFU} / \mathrm{g}$

The total psychotropic count observed in the present study (Table 5) was of $2.5 \pm 1.00 \mathrm{log}$ $\mathrm{UFC} / \mathrm{g}$, below the limit allowed by APHA for standard counting on aerobic microorganism plates (Compendium..., 2015). Total psychotropic counts were similar in the processed material and in the base fish pulp.
Higher initial psychotropic counts were reported by Guimarães et al. (2018), who demonstrated the need for this analysis to complement the RDC No. 12 set by ANVISA (Brasil, 2001). Total aerobic mesophilic counts were always below $2.00 \log \mathrm{CFU} / \mathrm{g}$.

Table 5. Total psychotropic counts (log CFU/g) in fish pulp and the processed meatballs and nuggets developed herein

\begin{tabular}{lcc}
\hline Samples $(*)$ & Initial & Storage after 30 days \\
\hline Tilapia pulp (C1) & 1.0 & $1.05 \pm 1.00$ \\
Trout pulp (C2) & 1.0 & 1.0 \\
Tilapia pulp meatball (C1) & 1.0 & $1.05 \pm 1.00$ \\
Trout pulp meatball (C2) & 1.0 & $1.45 \pm 1.00$ \\
Mixed pulp meatball (T1) & $1.10 \pm 1.00$ & $1.55 \pm 1.00$ \\
Mixed pulp meatball (T2) & 1.0 & $1.05 \pm 1.00$ \\
Mixed pulp meatball (T3) & 1.0 & $1.05 \pm 1.00$ \\
Mixed pulp meatball (T4) & 1.0 & $1.45 \pm 1.00$ \\
Tilapia pulp nugget (C1) & 1.0 & $1.05 \pm 1.00$ \\
Trout pulp nugget (C2) & 1.0 & 1.0 \\
Mixed pulp nugget (T1) & $1.10 \pm 1.00$ & $1.55 \pm 1.00$ \\
Mixed pulp nugget (T2) & 1.0 & $1.05 \pm 1.00$ \\
Mixed pulp nugget (T3) & $1.10 \pm 1.00$ & $1.55 \pm 1.00$ \\
Mixed pulp nugget (T4) & 1.0 & $1.05 \pm 1.00$ \\
\hline
\end{tabular}

$\left.{ }^{*}\right)$ Average for the samples $(\mathrm{n}=3)$ analyzed in triplicate; LOD: $\log 1.0 \mathrm{CFU} / \mathrm{g}$

The results obtained in the present study can be compared to those reported by Al-Asous and AlHarbi (2017) who, when evaluating these microorganisms in post-processed fish, obtained $4.15 \pm 0.06$ and $4.08 \pm 0.04 \log \mathrm{CFU} / \mathrm{g}$ for mesophilic and psycrotropic bacteria, respectively, corroborating the quality of good manufacturing practices employed in fish-based product development.

No histamine and sulfur-based compounds were detected in any of the samples. Thus, the 
histamine values detected in freshly processed ground meats and products are also in accordance with the Brazilian standard of 10 $\mathrm{mg} / 100 \mathrm{~g}$ (Brasil, 2017) and the North American standard of $5 \mathrm{mg} / 100 \mathrm{~g}$ (Food..., 2004). In the literature, findings ranging from 2 to $5 \mathrm{mg} / 100 \mathrm{~g}$ in codfish (Mársico et al., 2009) and less than 3 $\mathrm{mg} / 100 \mathrm{~g}$ in processed fish (Tsai et al., 2005) are available. Therefore, both the raw material and the processed products developed in the present study presented satisfactory hygienic-sanitary conditions, with no significant handling and processing interferences in product safety.

\section{CONCLUSIONS}

The aim of the present study was to develop foods exhibiting high nutritional potential and technologies capable of using processed fish products, resulting in standardized and practical foods products without losing functional and nutritional characteristics. In addition, the use of two food matrices may also be applied by producers in case of trout shortages, as tilapia is more abundant. The final products, despite being prepared from highly perishable raw material and undergoing numerous manipulations, displayed adequate microbiological counts, nutritional parameters and protein and lipid values, demonstrating the importance of applying good manufacturing practices when preparing fishbased foods to maintain product quality and avoid contamination.

\section{REFERENCES}

AGRESTI, A. Categorical data analysis. 2.ed. Nova Iorque: John Wiley \& Sons, 2002. 721p.

AL-ASOUS, A.I.; AL-HARBI, A.H. Microbiological and physicochemical quality of salted bluespot mullet (valamugil seheli) stored at different temperature. $J$. Food Saf., v.37, p.e12291, 2017.

AVDALOV, N.N. Beneficios del consumo de pescado. Uruguay: Dirección Nacional de Recursos Acuáticos, 2014. 30p.

BERIZI, E.; SHEKARFOROUSH, S.S.; HOSSEINZADEH, S. Effects of methanolic pomegranate peel extract on the chemical, sensory, textural, and microbiological properties of gutted rainbow trout (Oncorhynchus mykiss) during frozen storage. J. Food Prot., v.79, p.1700-1706, 2016.
BRASIL. Ministério da Saúde. Agência Nacional de Vigilância Sanitária (ANVISA). Resolução da diretoria colegiada- RDC $\mathrm{n}^{\circ} 12$, de 2 de janeiro de 2001. Aprova o regulamento técnico sobre padrões microbiológicos para alimentos, em anexo. Diário Oficial da União, Brasília, DF, n.7, 10 jan. 2001. Seção 1, p.45.

BRASIL. Ministério da Agricultura, Pecuária e Pesca. Instrução Normativa $N^{\circ} 21$, de 31 de maio de 2017. Ficam estabelecidos como oficiais os métodos constantes do manual de métodos oficiais para análise de alimentos de origem animal. Diário Oficial da União, Brasília, DF, n.108, 7 jun. 2017. Seção 1, p.5.

BRASIL. Ministério da Agricultura, Pecuária e Pesca. Instrução Normativa $N^{\circ} 30$, de 26 de junho de 2018. Ficam estabelecidos como oficiais os métodos constantes do manual de métodos oficiais para análise de alimentos de origem animal. Diário Oficial da União, Brasília, DF, n.134, 13 jul. 2018. Seção 1, p.9.

BYKOWSKI, P.J. Preparación de la pesca para su conservación y comercialización. 103-124. In: SIKORKI, E. (Org.). Tecnología de los productos del mar. Recursos, composición nutritiva y conservación. Zaragoza: Acribia, 1994. p.340.

COMPENDIUM of methods for the microbiological examination of foods. 3.ed. Washington: APHA, 2015. 1219p.

CONTRERAS-GUZMÁN, E.S. Bioquímica de pescados $e$ invertebrados. Jaboticabal: Fundação Universidade Estadual Paulista. 1994. 538p.

FONTES, M.C.; ESTEVES, A.; CALDEIRA, F.; SARAIVA, C. et al. Estado de frescor e qualidade higiênica do pescado vendido numa cidade do interior de Portugal. Arq. Bras. Med. Vet. Zootec., v.59, p.1308-1315, 2011.

FOOD additives and ingredients: overview of food ingredients, additives and colors. New Hampshre: FDA, 2004. Available in: https://www.fda.gov/Food/IngredientsPackagingLabel ing/FoodAdditivesIngredients/ucm094211.htm\#qanatu ral. Accessed in: 05 Sep. 2017.

GERMAN, B.J. Food processing and lipid oxidation. 23-50. In. JACKSON, L.S.; KNIZE, M.G.; MORGAN, J.N. (Orgs.). Impact of processing on food safety. Switzerland: Springer, 2012. 270p.

GRYSCHEK, S.F.B.; OETTERER, M.; GALLO, C.R. Characterization and frozen storage stability of minced Nile Tilapia (Oreochromis niloticus) and red tilapia (Oreochromis spp.). J. Aquat. Food Prod. Technol., v.12, p.57-69, 2003.

GUIMARÃES, J.L.B.; CALIXTO, F.A.A.; KELLER, .A.M. et al. Quality of mechanically separated meat (MSM) and surimi obtained from low commercial value fish. Bol. Inst. Pesca, v.44, p.e243, 2018. 
GÜMÜȘ, B.; İKIZ, R.; ÜNLÜSAYIN, M.; GÜLYAVUZ, H. Quality changes of salted red mullet (Mullus barbatus L., 1758) during vacuum packaged stored at + 4 C. Ege J. Fish Aqua. Sci., v.25, p.101104, 2008.

HILSDORF, A.W.S. Genetics and culture of red tilapia - a review. Bol. Inst. Pesca, v.22, p.73-84, 2018.

LOPES, I.G.; OLIVEIRA, R.G.; RAMOS, F.M. Perfil do consumo de peixes pela população brasileira. Biota Amaz., v.6, p.62-65, 2016.

MÁRSICO, E.T.; SILVA' C.; BARREIRA, V.B. et al. Parâmetros físico-químicos de qualidade de peixe salgado e seco (bacalhau) comercializado em mercados varejistas. Rev. Inst. Adolfo Lutz, v.68, p.520-529, 2009.

MOURA, E.; ARAÚJO, E.A.F.; LOURENÇO, L.F.H. et al. Reestruturado empanado elaborado com resíduo de pescada amarela (cynoscion acoupa) e adição da fibra de maracujá. CONGRESSO BRASILEIRO DE ENGENHARIA QUÍMICA, 20., 2014, Fortaleza. Anais... Fortaleza: COBEQ, 2014.

OFFICIAL methods of analysis of the association of official analytical chemistry. 18.ed. Gaithersburg: AOAC, 2005.

ONCORHYNCHUS mykiss. Fisheries and Aquaculture Department. Roma: FAO /FOOD, 2017. Available

http://www.fao.org/fishery/culturedspecies/Oncorhync hus_mykiss/en. Accessed in: 28 Jan. 2017.

ONCORHYNCHUS mykiss (Walbaum, 1792): Rainbowtrout. Introduzido por Susan M. Luna. modificado por Roxanne Rei Valdestamon. Espodede, POR.: FISHBASE, 2018. Available in http://www.fishbase.org/Summary/SpeciesSummary.p hp?ID=239\&AT=Rainbow+trout. Accessed in: 4 Feb. 2018.

PRÉCOMA, D.B.; OLIVEIRA, G.M.M. Atualização da diretriz de prevenção cardiovascular da Sociedade Brasileira de Cardiologia - 2019. Arq. Bras. Cardiol., v.113, p.787-891, 2019.

REBOUÇAS, M.C.; RODRIGUES, M.C.P.; CASTRO, R.J.S. et al. Characterization of fish protein concentrate obtained form the Nile tilapia filleting residues. Semin. Ciênc. Agrár., v.33, p.697-704, 2012.
RELATÓRIO anual 2014. Rio de Janeiro: FIPERJ, 2014. Disponível em: http://www.fiperj.rj.gov.br/fiperj_imagens/arquivos/re vistarelatorios2014.pdf. Acessado em: 16 de jan. 2018

RIBEIRO, D.S.; CALIXTO, F.A.A.; GUIMARÃES, J.L.B. et al. Produtos de pescado elaborados com resíduos de arrasto: análise físico-química, microbiológica e toxicológica. Arq. Bras. Med. Vet. Zootec., v.70, p.238-246, 2018.

SARY, C.; FRANCISCO, J.G.P.; DALLABONA, B.R. et al. Influência da lavagem da carne mecanicamente separada de tilápia sobre a composição e aceitação de seus produtos. Ciênc. Agrár. Ambient., v.7, p.423-432, 2009.

SIGNOR, A.A.; BOSCOLO, W.R.; FEIDEN, A. et al. Proteína e energia na alimentação de pacus criados em tanques-rede. Rev. Bras. Zootec., v.39, p.2336-2341, 2010.

SILVA, L.M.; SAVAY-DA-SILVA, L.K.; ABREU, J.G. et al. Determinação de índices morfométricos que favorecem o rendimento industrial de filés de tilápia (Oreochromis niloticus). Bol. Inst. Pesca, v.42, p.252257, 2016.

THE STATE of food insecurity in the world 2014 strengthening the enabling environment for food security and nutrition summit. Roma, Itália: FAO / FOOD, 2014.

TRATAMENTO não-medicamentoso ou modificações do estilo de vida. Rio de Janeiro: SBC, 2021. E colocar em ordem alfabética. Disponível em: http://departamentos.cardiol.br/dha/consenso3/tratame nto.asp. Acesso em: 24 mar. 2021.

TSAI, Y-H.; LIN, C.Y.; CHANG, S.C. et al. Occurrence of histamine and histamine-forming bacteria in salted mackerel in Taiwan. Food Microbiol., v.22, p.635-641, 2005.

VISENTAINER, J.V.; NOFFS, M.D.; CARVALHO, P.O. et al. Lipid Content and Fatty Acid Composition of 15 Marine Fish Species from the Southeast Coast of Brazil. J. Am. Chem. Soc., v.84, p.543-547, 2007. 